\title{
Evaluation of eating habits, body perception and depression status of university students
}

\author{
Ruhusen Kutlu (*), Selma Civi (*)
}

\begin{abstract}
The aim of this study was to determine the eating habits, body perception and depression status of the university students. This cross-sectional analytic study was performed among 262 students attending Vocational Education faculty of a university. The Eating Attitude Test (EAT), Beck Depression Inventory (BDI) were performed for all students. In our study, according to the results of EAT, $5 \%(n=13)$ had $\geq 30$ score (with eating disorders) and $95 \%$ was $<30$ score (without eating disorders). The mean scores of EAT in patients with eating disorders (EDs) and without EDs were $35.38 \pm 4.42$ and $13.33 \pm 5.78$ respectively. In terms of distrubition of body mass index (BMI), being underweight was significantly higher in girls and being overweight was higher in boys $(\mathbf{p}<\mathbf{0 . 0 0 1})$. When we compaired the mean value of age, Beck depresyon score and body mass index in patients with EDs and without EDs, statistically, we could not find any difference $(p>0.05)$. While weight loss and the idea on maintaining the same weight were significantly higher among females than males, the idea of weight gain was higher in males compared to females $(\mathbf{p}=\mathbf{0 . 0 0 4})$. In this research, doing physical exercise was insufficient in both genders. All university students should be provided with healthy nutrition conditions, sufficient and wellbalanced meals at low prices should be given and educational nutrition programs should be presented at certain intervals.
\end{abstract}

Key words: Body image, eating behavior, depression, student.

ÖZET

Üniversitesi öğrencilerinde yeme alışkanlığı, beden algısı ve depresyon durumunun değerlendirilmesi

Bu çalışmanın amacı üniversite öğrencilerinde yemek yeme alışkanlığı, beden algısı ve depresyon durumunun değerlendirilmesidir. Bu kesitsel tipteki analitik araştırma bir Üniversite Meslek Yüksek Mesleki Eğitim Fakültesine devam eden 262 öğrencide yapılmıştır. Tüm öğrencilere Yeme Tutum Testi (YTT) ve Beck Depression Ölçeği (BDÖ) uygulandı. Bu çalışmada YTT puanı $\geq 30$ olan 13 öğrencide (\%5) yeme bozukluğu vardı. YTT puanı $<30$ olan 249 öğrencide (\%95) yeme bozukluğu yoktu. YTT ortalama skoru yeme bozukluğu olan ve olmayanlarda sırası ile $35.38 \pm 4.42$ ve $13.33 \pm 5.78$ idi. Kemik mineral yoğunluğuna (KMY) göre düşük kilolu olma kızlarda, fazla kilolu olma durumu erkeklerde önemli ölçüde daha fazla idi $(\mathbf{p}<\mathbf{0 . 0 0 1})$. Yaş, Beck depresyon skoru ve KMY ortalama değerleri yeme bozukluğu olan ve olmayanlarda karşılaştıııldı̆ında istatistiksel olarak anlamlı bir farklılık bulunmadı $(p>0.05)$. Kilo kaybetme ve aynı kiloda kalma düşüncesi kızlarda önemli ölçüde daha yüksek iken, kilo alma düşüncesi erkeklerde kızlara göre daha yüksek idi $(\mathbf{p}=\mathbf{0 . 0 0 4})$. Bu araştırmada egzersiz yapma her iki cinsiyette de yetersiz idi. Tüm üniversite öğrencilerine sağlıkı beslenme koşulları sunulmalı, öğrencilere düşük ücretle yeterli ve dengeli menülerden oluşan öğünler verilmeli, belli aralıklarla beslenme eğitimi programları uygulanmalıdır.

Anahtar kelimeler: Beden algısı, yeme alışkanlığı, depresyon, öğrenci.

* Department of Family Medicine, Meram Medical Faculty, University of Konya, Konya/Turkey

Reprint request: Ruhusen Kutlu, Department of Family Medicine, Meram Medical Faculty, University of Konya

E-mail: ruhuse@yahoo.com

Date submitted: July 23, 2012 Date accepted: April 21, 2013 Online publication date: September 26, 2013

\section{Introduction}

An adequate and balanced diet is one of the fundamental conditions and perhaps the most important one for healthy living of individuals and societies, their economic and social development, in increasing the level of their welfare, and helping them lead happy and peaceful lives in safety (1-3). Therefore, nutrition is one of the most important and frequently discussed subjects today (4).

Nutrition is an activity that has to be performed carefully in order to take in nutrients in adequate quantities and at appropriate times for the purpose of maintaining and improving health and raising the quality of life $(5,6)$. Nutrition is an indispensable part of our lives in the process that begins in the mother's womb and ends in death (7).

Today, young people are faced with very many health problems, either biological or psycho-social. However, unhealthy and imbalanced diet habits and ensuing diseases top the list of these problems (8). Research on nutrition indicates that overnutrition as well as inadequate nutrition has an adverse effect on health. It is possible to observe various diseases in the society connected with nutrition and their level of welfare. In short, health problems change form depending on the form of nutrition (9).

Adolescence is a specific period in human life when growth and development are at the fastest and covers transition from childhood to adulthood. The nutrition-related problems in school age children and young people in Turkey involve problems connected with thinness, obesity, avitaminoses, anemia, goiter and tooth decays (8). Besides them, it has been reported that inadequate and imbalanced nutrition shortens students's attention time, reduces their perception and leads to difficulty in learning and behavioral disorders as well as absenteeism and a drop in success at school (9-11). 
Exercise is a universal and integrative activity that societies can not ignore, interrupt and forsake. Thus, the phenomenon of exercise, which has become a criterion for civilisation in today's world, requires its popularisation and generalisation (11). A significant portion of the higher education students receive their education away from their families and this situation leads to difficulties concerning nutrition, accomodation, school expenditures, and health issues. Nutrition is in itself a problem especially for students who stay in dormitories $(10,11)$.

Studies conducted in our country on the nutrition habits of students have reported that very serious problems are experienced in this period in terms of nutrition, that students generally do not follow meal times, miss meals notably breakfast, consume sesame rolls and tea extensively and that young people consider eating one's fill equal to nutrition (8). Eating disorders (EDs) are characterized by clinically significant disturbances in eating behavior. They are often accompanied by another psychiatric disorder such as depression and anxiety (12). Eating Attitude Test- 40 (EAT) is a widely used self-report measure of EDs, and it has been used in nonclinical samples as a general screening measure for disordered eating attitudes.

In this study, we aim to evaluate university students' eating habits by using EAT-40, body perceptions, depression status and in the light of obtained data describe what can be done to gain them healthy nutrition habits and achieve a healthier society in the long run.

\section{MATERIALS AND METHODS}

\section{Study design, setting and population}

This is a cross-sectional analytic study that was conducted on 262 students who attended Vocational Education faculty of a university. The population of the study consisted of all the students who received education at the school between 10 February 2008 and 30 June 2008. The rate of participation in the study was $95.2 \%$. The study protocol was approved by the Ethics Committee of the Medical faculty of a university. A study protocol was determined, approval was received from the Dean of Faculty of Vocational Education and and then interviews were held with students in classrooms. Students were given information about the study and their oral and written consents were obtained. Those who were not at school at the specified dates for various reasons and those who refused to take part in the study were not included in the study. A questionnaire form that was developed by the researchers in accordance with the relevant literature and consisted of two sections was used as the data collection tool. The first section contained questions aimed at determining the students' socio-demographic and family characteristics. At the second section, the Eating Attitude Test (EAT) and Beck Depression Inventory (BDI) were performed for all students.

\section{Eating Attitude Test (EAT)}

EAT-40 is a widely used self-report measure of EDs, and although it was developed by Garner and Garfinkel in 1979 and it has been used in nonclinical samples as a general screening measure for disordered eating attitudes. EAT-40 was adapted to Turkish by Erol and Savasir in 1989 (12,13). The Turkish version of EAT consists of 40 questions, the answers to which are evaluated with a six-point Likert scale, from "always" to "never." The resulting scores range between 0 and 120 points, and individuals scoring $\geq 30$ points are considered as at high risk of EDs (13).

\section{Beck Depression Inventory (BDI)}

This questionnaire included 21 items and revealed the participants' depression level. The information on depressed mood and anxiety was obtained by this Beck Depression Inventory (BDI). If the total score was under 9, it was regarded as nondepressive (normal), 9-16 mild, 17-29 moderate, 30 and over severe depression respectively. The cut-off point of BDI was taken as $17(14,15)$.

\section{Antropometric Measurements}

Anthropometric measurements (body weight, height) of the students were taken by the same researcher in order to reduce error rate. Their heights were measured using a height measure without shoes on them and their weights were measured using standard scales after their jackets and other excess clothes on them were removed. The students' heights and weights were meausured and their body mass indexes (BMI) were calculated using the formula $(\mathrm{BMI})=$ Weight $(\mathrm{kg}) / \operatorname{Height}^{2}(\mathrm{~m})$. According to the World Health Organization classification, BMI lower or equal to $18.50 \mathrm{~kg} / \mathrm{m}^{2}$ is defined as underweight, between 18.50 and 24.99 is considered as ideal weight 
(normal) for individuals. Overweight is defined as BMI between $25.00-29.99 \mathrm{~kg} / \mathrm{m}^{2}$, and obesity is defined as body mass index above $30 \mathrm{~kg} / \mathrm{m}^{2}$ (16).

\section{Statistical Analysis}

The encoding and statistical analyses of the data were performed on the computer using the SPSS 13.0 package software. The minimum, maximum, mean, standard deviation, median and percentages were used in the analysis of the data and chi-sqare test and student $t$ - test were used as the significance test. The significance level was taken as $\mathrm{p}<0.05$.

\section{RESULTS}

\section{Sociodemographic data}

A total of 262 university students (156 females, 106 males, age range $18-34$, mean age $21.72 \pm 2.38$ ) were included in the study. 31 students stayed with their families, whereas 171 (65.3\%) students stayed in the dormitory. While $8 \%$ of the students found their pocket money insufficient, $66.4 \%$ of them found it sufficient and $1.9 \%$ found it very sufficient. Of the families, $67.9 \%$ had medium level income, $96.6 \%$ of the students did not use alcohol and $90.5 \%$ of them did not smoke ( $\mathrm{n}=237), 78.25 \%$ of the students did not exercise, $63.7 \%$ of the mothers were primary school educated and $90.8 \%$ of them were housewives, $46.2 \%$ of the fathers were primary school educated and $35.9 \%$ of them were retired. When we examined the body perceptine, $27.1 \%$ of the students found their weights below normal, $47.7 \%$ normal and 25.2 $\%$ above normal. The students who were thinking of losing weight were $28.6 \%$, those wanted to gain weight were $17.6 \%$ and those wished to maintain their weight were $20.2 \%$. Of the students, $21.8 \%$ had taken exercise to lose weight during the past 3 months, $32.1 \%$ have eaten less food in the past 3 months and $3.1 \%$ had taken any drugs to lose weight. Statistically, there was no significant difference in gender, mother and father occupation, mother and father education and marital status between students with EDs and without EDs ( $p>0.05$ ).

\section{Eating Attitude Test (EAT) results}

In our study, according to the results of EAT, 5\% $(n=13)$ had $\geq 30$ score (with eating disorders) and 95\% was $<30$ score (without eating disorders). The mean scores of EAT in patients with EDs and without EDs were $35.38 \pm 4.42$ and $13.33 \pm 5.78$ respectively. When we studied the differences of opininon between girl and boy students about weight, the exact normal kilo and nearly over normal were more in girl students $(\mathrm{p}=$ 0.004). When we investigated the differences of the ideas about weight, we observed that the thoughts of losing weight and keeping the same weight were higher in girls and the thought of gaining weight was considerably higher in boys $(\mathrm{p}=\mathbf{0 . 0 1 2})$. The thought of eating less food in the past three months was higher in girls $(\mathrm{p}=\mathbf{0 . 0 3 1})$ (Table 1$)$. The mean values of eating attitudes test, BMI and Beck depression scores of university students were shown in Table 2 . The BMI values of boy and girl students were shown in Table 3. In terms of distrubition of BMI, being underweight was significantly higher in girls and being overweight was higher in boys $(\mathbf{p}<\mathbf{0 . 0 0 1})$. The mean scores of age, BDI and BMI in patients with EDs and without EDs were presented in Table 4 . When we compared the mean scores of age, beck depresyon score and body mass index in patients with EDs and without EDs, statistically, we could not find any difference $(\mathrm{p}>0.05)$.

\section{Depression results}

The mean BDI score was $11.1 \pm 6.8$ (median $=10$, $\min =0, \max =38$ ). According to the results of the Beck Depression Inventory (BDI); 48.5\% ( $\mathrm{n}=127), 30.9 \%$ $(\mathrm{n}=81), 19.1 \%(\mathrm{n}=50), 1.5 \%(\mathrm{n}=4)$ were normal, mild, moderate, severe depression respectively. When the cut-off point of BDI was taken as 17, 208 participants (79.4\%) had scores of 16 and under, and 54 (20.6\%) had scores of 17 and over, respectively. When we compared the results of the Beck Depression Inventory and BMI, depression was higher 2. 247 times among obese students [OR=2.247,\%95 CI; (0.941-5.368)]. Depression status was observed 1.769 times higher in the individuals EAT scoring $\geq 30$ points. [OR=1.769,\%95 CI; (0.523-5.979)].

Of the 13 individuals with EAT scores $\geq 30$ points, four cases $(30.8 \%)$ presented depression.

The depression was observed in 50 (20.1\%) students who have normal EAT score. The relation between depression and EAT, BMI was not significant $(\mathrm{p}>0.05)$.

\section{Body Perception}

There was a significant relation between body perception and EAT scores $(\mathbf{p}=\mathbf{0 . 0 4 6})$. The EAT score was considerably higher in the students who regard themselves as obese. When we investigated the 
Table I. Differences of opininon between girl and boy students about weight

\begin{tabular}{|c|c|c|c|c|c|c|c|}
\hline \multirow{2}{*}{ How do you describe your weight } & \multicolumn{2}{|c|}{$\begin{array}{l}\text { Girl } \\
n \%\end{array}$} & \multicolumn{2}{|c|}{$\begin{array}{l}\text { Boy } \\
n \% \\
\end{array}$} & \multicolumn{2}{|c|}{$\begin{array}{c}\text { Total } \\
n \%\end{array}$} & $p$ \\
\hline & & & & & & & \\
\hline Below normal & 14 & 46.7 & 16 & 53.3 & 30 & 100.0 & \\
\hline Almost below normal & 17 & 41.5 & 24 & 58.5 & 41 & 100.0 & \\
\hline The exact normal kilo & 87 & 69.6 & 38 & 30.4 & 125 & 100.0 & 0.004 \\
\hline Almost above normal & 32 & 62.7 & 19 & 37.3 & 51 & 100.0 & \\
\hline Above normal & 6 & 40.0 & 9 & 60.0 & 15 & 100.0 & \\
\hline \multicolumn{8}{|l|}{ Their ideas about weight } \\
\hline I do not do anything about my weight & 50 & 56.8 & 38 & 43.2 & 88 & 100.0 & \\
\hline I am thinking of losing weight & 49 & 65.3 & 26 & 34.7 & 75 & 100.0 & 0.012 \\
\hline I am thinking of gaining weight & 19 & 41.3 & 27 & 58.7 & 46 & 100.0 & \\
\hline I am thinking of maintaining the same weight & 38 & 71.7 & 15 & 28.3 & 53 & 100.0 & \\
\hline \multicolumn{8}{|c|}{ Have you done any exercises in the past three months? } \\
\hline Yes & 35 & 61.4 & 22 & 38.6 & 57 & 100.0 & 0.864 \\
\hline No & 121 & 59.0 & 84 & 41.0 & 205 & 100.0 & \\
\hline \multicolumn{8}{|l|}{ Have you eaten less food in the past three months? } \\
\hline Yes & 58 & 69.0 & 26 & 31.0 & 84 & 100.0 & 0.031 \\
\hline No & 98 & 55.1 & 80 & 44.9 & 178 & 100.0 & \\
\hline \multicolumn{8}{|c|}{ Have you stayed hungry in the past three months to lose weight? } \\
\hline Yes & 3 & 37.5 & 5 & 62.5 & 8 & 100.0 & 0.202 \\
\hline No & 153 & 60.2 & 101 & 39.8 & 254 & 100.0 & \\
\hline \multicolumn{8}{|c|}{ Have you taken any drugs to lose weight in the past three months? } \\
\hline Yes & 5 & 62.5 & 3 & 37.5 & 8 & 100.0 & 0.862 \\
\hline No & 151 & 59.4 & 103 & 40.6 & 254 & 100.0 & \\
\hline
\end{tabular}

Table II. Results of EAT, BMI and BDI of university students

\begin{tabular}{lccccc}
\hline & Mean & SD & Median & Min & Max \\
\hline EAT & 14.43 & 7.47 & 13 & 3 & 44 \\
BMI & 21.47 & 2.94 & 21.22 & 12.61 & 33.94 \\
BDI & 11.08 & 6.77 & 10.00 & 0.0 & 38.0 \\
\hline
\end{tabular}

EAT= Eating Attitudes Test, BMI= Body Mass Index, BDI= Beck Depression Inventor

differences of body perception and BMI, we observed that BMI was found at normal level in the students who consider themselves below normal and above normal weight. There was a significant relation between body perception and BMI $(\mathbf{p}<0.001)$.

\section{DISCUSSION}

The ideals of having a career and shaping their future during the university years and the efforts aimed at adapting to a new school and environment lead to various social, psychological and health problems in many students (11). Nutrition needs increase due to the rapid growth and changes in the body during adolescence. Therefore, a healthy diet is of vital importance in adolescents. In our study, according to the results of EAT, 5\% $(n=13)$ had $\geq 30$ score (with eating disorders) and $95 \%$ was $<30$ score (without eating disorders).

In this study, $27.1 \%$ of the students considered themselves below normal weight, $47.7 \%$ at normal weight and $25.2 \%$ above normal weight. The rate of those who wanted to lose weight was $31.4 \%$ in girls and $24.5 \%$ in boys whereas the rate of those wanted to maintain the same weight was $24.4 \%$ in girls and $14.2 \%$ in boys. It is observed that the desire to maintain the same weight and losing weight are more 
Table III. Distrubition of boy and girl students'BMI values

\begin{tabular}{|c|c|c|c|c|c|c|}
\hline \multirow{2}{*}{ BMI } & \multicolumn{2}{|c|}{ Girl Students } & \multicolumn{2}{|c|}{ Boy Students } & \multirow{2}{*}{$\begin{array}{c}\text { Total } \\
n\end{array}$} & \multirow{2}{*}{$p$} \\
\hline & $n$ & $\%$ & $n$ & $\%$ & & \\
\hline$<18.5$ & 31 & 93.9 & 2 & 6.1 & 33 & \multirow{4}{*}{0.000} \\
\hline $18.5-24.99$ & 118 & 58.4 & 84 & 41.6 & 202 & \\
\hline $25-29.99$ & 6 & 24.0 & 19 & 76.0 & 25 & \\
\hline$\geq 30$ & 1 & 50.0 & 1 & 50.0 & 2 & \\
\hline
\end{tabular}

Table IV. Mean scores of age, BDI and BMI in patients with EDs and without EDs

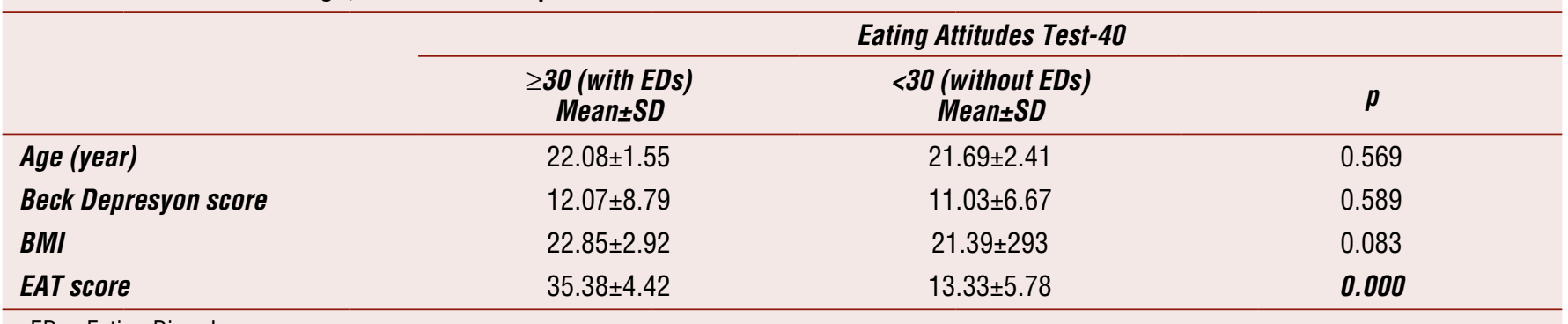

EDs= Eating Disorders

predominant in girls than in boys. A study conducted by Sakamaki et al (17), on university students found that young Chinese female students had a greater desire to be thinner (62.0\%) than males (47.4\%).

Exercise is a means of achieving the goals of revealing one's own self-power, forming habits of group work, solidarity, sincerity of action and honesty, and creating and developing a healthy body and mind (8). In our study, the rate of those who said "yes" to the question "did you take exercise in the past three months?" was $21.8 \%$. Rodriquez et al (18) found the rate of taking daily exercise among adolescents as $38.3 \%$. In Kara's study (2), the rate of those who went on a diet in the past 30 days for the purpose of slimming or maintaining their weight was found to be $34.2 \%$ and the rate of taking exercise was $48.1 \%$. The rate of taking regular exercise have been found to be inadequate in all studies.

In a study conducted by Simsek et al (19), the frequency of taking exercise was $63.6 \%$ among the students at Harran University. Therefore, it is thought that students should be encouraged to take regular exercise in order to develop healthy life behaviors.

In our study, $37.2 \%$ of the girls $(n=58)$ and 24.5 $\%$ of the boys $(n=26)$ stated that they ate less food to lose weight. The difference was found to be statistically significant( $\mathbf{p}=\mathbf{0 . 0 0 4})$. Of the students, $21.8 \%$ had taken exercise to lose weight during the past 3 months, $32.1 \%$ have eaten less food in the past 3 months.
In a study conducted by Ozmen et al (4), $36.7 \%$ of the students stated that they feared getting fat and girls feared getting fat at a significantly higher rate than boys. The percentage of "I always want to be thin" was significantly higher among the girl students. It has been observed in many studies that girl students more than boy students always want to be thin due to the fact their aesthetic worries outweigh boys' in early adulthood $(20,21)$.

Of the participants, $3.1 \%$ had taken any drugs to lose weight. A study conducted by Tomori and Rus-Makovec (20) found the rate of using laxatives by students among the methods of reducing body weight as $0.8 \%$ among girls and $0.2 \%$ among boys, which pointed to a significant difference between the sexes and it was pointed out that girls used methods of reducing body weight more frequently. The high rate of dieting among girl students to control body weight is an expected result and what is important here is the implementation of such dietary practices under health counsellors.

In our study, being 18.5 and below (thin) according to BMI was higher among girls (19.1\%), whereas being overweight and obese was higher among boys (19.9\%). In a study conducted by Orak et al (22) on 712 students at Süleyman Demirel University, boys and girls were, according to BMI, thin by 2.74 $\%$ and $17.19 \%, 81.92 \%$ and $78.13 \%$ were normal, $14.52 \%$ and $3.75 \%$ were overweight and $0.82 \%$ and $0.94 \%$ were obese respectively. These results are in 
conformity with our findings. A study conducted by Aksoydan (23) stated that results of the study showed that $5.6 \%, 14.7 \%$ and $4.1 \%$ of the students were underweight, overweight and obese, respectively. Of all the adolescents, $79 \%$ and $6.6 \%$ were physically inactive and active, respectively.

The increasing rate of obesity may lead to deviations from the normal especially among adolescent girls for whom body perception gains significance (24). A quick loss of weight as a result of uninformed dietary practices to get rid of excess weight may affect whole body systems and lead to severe hormonal amd metabolic disorders (25). Implementation of a balanced slimming diet appropriate for the age, sex and life style under the supervision of doctors and diet experts increases rate of success and prevents occurrence of psychiatric, endocrinologic and metabolic problems.

In this study, the level of exercise was inadequate in both sexes. The idea of gaining weight was higher among the boys while the ideas of losing weight and being afraid of fatness were more predominat among the girls. The nutritive requirements of young people are higher in comparison to other age groups as they grow fast and lead a more active life. The nutritional habits of these young people who will constitute a significant portion of the human resources in the future are not known properly. All university students should be provided with health nutritional conditions; students should be offered meals containing adequate and balanced menus at a low cost; nutrition education programs should be implemented at regular intervals; young people should be encouraged to take exercise and appropriate spaces should be created to this end. The identification of prototypical eating habits patterns revealed a large range of wrong eating attitudes and behaviours among Turkish adolescents. Such data suggest the need to develop and implement adequate prevention programs.

\section{References}

1. Kann L, Kinchen SA, Williams BI, et al. Youth Risk Behavior Surveillance-United States, 1997. State and Local YRBSS Coordinators. J Sch Health 1998; 68: 355369.

2. Kara B, Hatun S, Aydogan M, Babaoglu K, Gökalp AS. Evaluation of the health risk behaviors of high school students in Kocaeli. Turkish Pediatric Journal 2003; 46: 30-37.
3. Arata A, Battini V, Chiorri C, Masini B. An exploratory survey of eating behaviour patterns in adolescent students. Eat Weight Disord 2010; 15: 200-207.

4. Ozmen D, Cetinkaya AC, Ergin D, Sen N, Erbay PD. Eating Habits and Body Weight Control Behaviors of High School Students. TAF Prev Med Bull 2007; 6: 98105.

5. Wang Y, Liang H, Chen X. Measured body mass index, body weight perception, dissatisfaction and control practices in urban, low-income African American adolescents. BMC Public Health 2009; 9: 183-194.

6. Jackson RT, Rashed M, Saad-Eldin R. Rural urban differences in weight, body image, and dieting behavior among adolescent Egyptian schoolgirls. Int J Food Sci Nutr 2003; 54: 1-11.

7. Bauer KW, Larson NI, Nelson MC, Story M, NeumarkSztainer D. Socio-environmental, personal and behavioural predictors of fast-food intake among adolescents. Public Health Nutr 2009; 12: 1767-1774. Epub 2008 Dec 24.

8. Oksuz E. Unhealthy body perception among Turkish youths: socioeconomic status and social comparisons. Coll Antropol 2008; 32: 5-13.

9. Davy SR, Benes BA, Driskell JA. Sex differences in dieting trends, eating habits, and nutrition beliefs of a group of midwestern college students. J Am Diet Assoc 2006; 106: 1673-1677.

10. Nelson MC, Kocos R, Lytle LA, Perry CL. Understanding the perceived determinants of weight-related behaviors in late adolescence: a qualitative analysis among college youth. J Nutr Educ Behav 2009; 41: 287-292.

11. Sakamaki R, Amamoto R, Mochida Y, Shinfuku N, Toyama K. A comparative study of food habits and body shape perception of university students in Japan and Korea. Nutrition Journal 2005; 4: 31-36.

12. Garner DM, Garfinkel PE. The eating attitudes test: an index of the symptoms of anorexia nervosa. Pyschol Med 1979; 9: 273-279.

13. Erol N, Savasir I. Eating attitude test: index of anorexia nervosa symptoms. Turkish Journal of Psychology 1989; 23: 132-136.

14. Beck AT, Ward CH, Mendelson M, Mock J, Erbaugh J. An inventory for measuring depression. Arch Gen Psychiatry 1961; 4: 561-571.

15. Hisli N. Reliability and validity study of Turkish version of Beck depression inventory. Turkish Psychol J 1988; 6: 118-122.

16. Measuring obesity - classification and description of anthropometric data: report on a WHO consultation on the epidemiology of obesity: Warsaw 21-23 October 1987. http://books.google.com.tr/books/ about/Measuring_obesity_classification_and_des.html. Accessed 15 Oct 2011.

17. Sakamaki R, Toyama K, Amamoto R, Liu CJ, Shinfuku N. Nutritional knowledge, food habits and health attitude of Chinese university students -a cross sectional study. Nutrition Journal 2005; 4: 1-5. 
18. Rodriquez A, Novalbos JP, Martinez JM, Ruiz MA, Fernandez JR, Jimenez D. Eating disorders and altered eating behaviors in adolescents of normal weight in a Spanish city, Journal of Adolescent Health 2001; 28: 338- 345.

19. Simsek Z, Koruk İ, Altındag A. Health Risk Behaviors of First Year Students of Harran University Medical Faculty and Faculty of Science and Letters. Public Health Bull 2007; 26: 19-24.

20. Tomori M, Rus-Makovec M. Eating behavior, depression, and self-esteem in high school students, Journal of Adolescent Health 2000; 26: 361-367.

21. Ercan O, Alikasifoglu M, Erginoz E, Kaymak-Albayrak D, Birol HI, Aktuglu-Zeybek C. The prevalence of risky behaviour among İstanbul high-school students and distribution of these behaviours by gender. Turkish Archives of Pediatrics 2001; 36: 199-211.

22. Orak S, Akgün S, Orhan H. Investigation of nutritional habits of Suleyman Demirel University students. Journal of Süleyman Demirel University Medic Fac 2006; 13: 5-11.

23. Aksoydan E, Cakır N. Adölesanların beslenme alışkanlıkları, fiziksel aktivite düzeyleri ve vücut kitle indekslerinin değerlendirilmesi. Gülhane Tıp Derg 2011; 53: 264-270

24. Stoving R, Hangaard J, Hagen C. Update on endocrine disturbances in anorexia nervosa. J Pediatr Endocrinol Metab 2001; 14: 459-480.

25. Demirel F, Bideci A, Camurdan O, Yesilkaya E, Cinaz P. Hypothyroidism developing in adolescent girls who lost weight with inappropriate diets. Sted 2005; 14: 188-191. 